aumerous cases there are transitions both in form and in property between non-pathogenic and pathogenic bacteria.

As another instance showing how opinions are beginning to change at the expense of ultra-contagionist doctrines I may say that quite recently Dr. E. O. Seaton has kindly sent me his annual report as medical officer of health of the county of Surrey, in which after a most careful inquiry into the seasonal prevalence and the distribution of typhoid fever in the county he says (p. 39): "I believe that Dr. Pierce of Guildford and other careful observers in our county could furnish Dr. Bastian with examples of typhoid occurring in isolated country dwellings or under conditions where chances of infection could be definitely excluded." Further, he goes on to express his own opinion in these precise terms: "Personally I agree that cases occur from time to time in purely country districts which it is absolutely impossible to connect with any previous case, and which suggest the possibility of new origin (i.e., apart from human infection) through bacilli other than those which are regarded as the invariable specific cause of typhoid." Mutatis mutandis that is precisely what I am contending for in regard to phthisis and other communicable diseases.

$$
\begin{aligned}
& \text { I am, Sirs, yours faithfully, } \\
& \text { H. CHARLTON BASTIAN. }
\end{aligned}
$$

\section{THE MEDICAL SCHOOL OF ST. THOMAS'S HOSPITAL AND THE CONCENTRATION OF EARLY MEDICAL STUDY. To the Editors of THE LANCET.}

SiRs, - At the date of the recent election by the Faculty of Medicine of their representatives on the senate of the University of London, an impression obtained that St. Thomas's Hospital was no longer whole-hearted in support of an Institute of Medical Sciences at South Kensingtion. This impression is entirely erroneous and in view of the meeting of the faculty summoned for next week it seems desirable that it should be corrected.

St. Thomas's has throughout been consistent in its opinions on this question and still desires to afford its support to the senate in the steps which the University has taken, on the recommendation of the faculty, to establish an institute at South Kensington. The treasurer of St. Thomas's is a member of the committee appointed by the senate to obtain financial help for this scheme; the staff and lecturers continue to give their unanimous support to the proposal; they believe it to be one of the most important steps which can be taken and which are so urgently needed to strengthen the position of the metropolis as the chief centre of medical education in the United Kingdom.

I am, Sirs, yours faithfully,

J. HERBERT FISHER,

June 17th, 1907

Dean of the Medical School, St. Thomas's Hospital.

\section{BEES' 'STINGS AND RHEUMATISM.}

To the Editors of THE LANCET.

SIRs, - In the course of an inquiry into the relation which I have been led to suppose may exist between certain manifestations of rheumatism and an abnormal production of formic acid in the tissues my attention has been called from time to time to a curious belief which appears to be prevalent in various parts of the country. This very interesting piece of folk lore is to the effect that frequent exposure to the stings of bees (as among bee-keepers) is both protective and curative for rheumatism. My correspondence leads me to conclude that this belief is widely disseminated and is probably familiar to many of your readers.

May I, therefore, be allowed the privilege of making the following inquiries (through your correspondence column) of any of your readers who are sufficiently interested in the question to send me such information as has come within their own knowledge? 1. Have you met with the belief that bees' stings cure or prevent rheumatism? 2. Do you know any case in which a rheumatic subject claims to have benefited in this way as the result of working among bees? 3. Are you acquainted with any reliable evidence which supports or explains the origin of this belief? 4 . What were the characters of the "rheumatism" in question?

I am, Sirs, yours faithfully,

E. W. AINLEY-WALKER.

University College, Oxford, June 17th, 1907.

\section{THE SOCIETY OF APOTHECARIES OF LONDON BILL, 1907. \\ To the Editors of THE LANCET.}

SIRs,--This Bill having been passed by both Houses of Parliament now only awaits the Royal Assent to become law. It changes the title of L.S.A. to the more appropriate one of Licentiate in Medicine and Surgery and gives authority to the Society to confer the latter title by diploma on all of its Licentiates who have qualified since June 30th, 1887. Authority is also given to the General Medical Council to enter the new description on the Medical Register. Power is given to the Society to restore (with the consent of the Medical Council) the name of any Licentiate who may have been removed from the roll. Heretofore the Society had only the power to remove a name. The cost of obtaining this Act has been considerable and the council of the Association of Physicians and Surgeons of the Society of Apothecaries undertook to raise $£ 250$ towards it. Of this sum £222 5s. $6 d$. have been subscribed by the Licentiates, £25 was voted by the Association from its funds, leaving a deficit of $£ 214 s .6 d$. The expenses of collection amount to $£ 131 s$. 9d., bringing the total deficit to $£ 1516 s$. $3 d$. May I ask those Licentiates who have omitted to send a donation to send their contributions to me without delay? It is scarcely fair that the members of the council of the Association who have had all the hard work, and who have already borne more than their share of the expenses, should also be saddled with this deficit. I am, Sirs, yours faithfully, A. RIVERS-WILLSON.

42, Wellington-square, Oxford, June 17th, 1907.

\section{HAMOGREGARINES IN SNAKES. \\ To the Editors of THE LANCET.}

SIRS,-In the abstract of the paper on Hæmogregarines in Snakes (read at the Pathological Society on June 4th) which you published in THE LANCET of June 15th you omitted Dr. C. G. Seligmann's name, although the paper was in fact a conjoint publication. I should be most obliged if you would mention this in your next issue.

I am, Sirs, yours faithfully,

Palace Gardens Mansions, W., June 18th, 1907.

LouIs W. SAMBON.

\section{THE WEST LONDON HOSPITAL DINNER. To the Editors of THE LANCET.}

SIRS,-In the account of the West London Hospital and Post-Graduate College dinner given in THE LANCET of June 15th, you say it was under the presidency of $\mathrm{Mr}$. $E$. Lloyd Williams. It is a curious mistake to have made. There is a Mr. E. Lloyd Williams, but I was the chairman of the dinner and am the dental surgeon to the hospital.

I am, Sirs, yours faithfully,

H. LLOYD WILliams.

Upper Wimpole-street, W., June 19th, 1907.

\section{THE ASSOCIATION OF PUBLIC VACCI- NATORS OF ENGLAND AND WALES.}

To the Editors of THE LANCET.

SIRs,-A meeting of delegates appointed by the 37 representative councils of the Association of Public Vaccinators of Fngland and Wales was held in London yesterday. The delegates represented over 3000 members of the medical profession who are public vaccinators and the following was one of the resolutions passed at the meeting :-

That this representative meeting of the public vaccinators of England and Wales emphatically protests against the provisions of the New Vaccination Order, which suggest the reduction of the existing minimum fees to public vaccinators and points out that, although the Departmental Committee reported that if the public vaccinator were made an officer, only removeable with the consent of the Local Government Board and eligible for superannuation, it might be fair to make some reduction of fees; the new Order not only refuses to the public vaccinator the position which is his just claim, and leaves him still under contract without right of appeal; but also reduces the minimum fees for domiciliary vaccination even lower than the committee suggested.

That in the opinion of this meeting it is impossible for the work to be remunerative at the minimum fees in any district in Fngland and Wales under existing circumstances, and that the proposed reduction 